\section{Rеgев́rн Article: Production potential of maize as influenced by crop residue incorporation and nitrogen levels in legume- cereal sequence}

\author{
口. AMMAJI AND CH. PULLA RAO
}

Article Chronicle : Received :

14.07.2017;

Accepted :

29.07.2017

KEY WoRds:

Crop residue,

Legume- maize

sequence, Nitrogen

levels

Author for correspondence :

\section{P. AMMAJI}

Department of

Agronomy, Agricultural

College,

RAJAMAHENDRAVARAM

(A.P.) INDIA

Email: ammajiagronomy

@ gmail.com

See end of the article for

authors' affiliations
SUMMARY : Field experiments were conducted during 2011-12 and 2012-13 at Agricultural College, Aswaraopet with an objective to find the influence of Kharif legume, residue management practices and nitrogen levels on the performance of succeeding maize. The treatments consists of three legume crops, viz., cowpea, fieldbean and greengram as Kharif legume crops, two residue management practices viz., residue removal $\left(\mathrm{I}_{0}\right)$, Residue incorporation $\left(\mathrm{I}_{1}\right)$ as sub plotsand four nitrogen levels $(75,150,225$ and $300 \mathrm{~kg} \mathrm{ha}^{-1}$ ) as sub-sub plot plots allocated to maize. The growth, yield and yield attributing characters like drymatter accumulation, kernel rows per cob, number of kernels per cob and yield were significantly influenced by Kharif legume crops, residue management practices and nitrogen levels. The highest drymatter accumulation of maize was observed when cow pea was taken as a preceding was found to increase the yield of succeeding maize byseven per cent over the residue removal. Application of nitrogen @ $300 \mathrm{~kg} \mathrm{ha}^{-1}$ was found significantly superior to 75 and $150 \mathrm{~kg} \mathrm{~N} \mathrm{ha}^{-1}$ and comparable with $225 \mathrm{~kg} \mathrm{~N} \mathrm{ha}^{-1}$. Incorporation of previous crop residues in conjunction with $300 \mathrm{~kg} \mathrm{~N}$ $\mathrm{ha}^{-1}$ may be adopted to enhance the productivity of maize in legume - maize sequence.

How to cite this article : Ammaji, P. and Rao, Ch. Pulla (2017). Production potential of maize as influenced by crop residue incorporation and nitrogen levels in legume- cereal sequence. Agric. Update, 12 (TECHSEAR-4): 1063-1066; DOI: 10.15740/HAS/AU/12.TECHSEAR (4)2017/1063-1066. crop to maize followed by field bean and greengram. Incorporation of residues of previous legumes 